\title{
Pasture botanical composition and forage quality at farm scale: A case study
}

\author{
Cristina Pornaro, Elena Basso, Stefano Macolino \\ Department of Agronomy, Food, Natural resources, Animals, and Environment, University of Padova, \\ Legnaro (PD), Italy
}

\begin{abstract}
The importance of maintaining mountain pastures in preserving environmental services is widely known. However, in mountainous regions, environmental and vegetation heterogeneity at the farm scale affect farm management. This study was conducted at the summer pasture of Malga Serona (northeastern Italy) to introduce a discussion of appropriate management at the farm scale. Forty botanical surveys were performed, where an herbage sample from a $100 \times 100 \mathrm{~cm}$ surface was collected in each survey. The number of species, the average Landolt index, and the pastoral value (PV) were calculated for each survey. For each herbage sample, nutrient content was measured. We observed differences in botanical composition and in forage quality within the study area. We found that the PV varied from 35.6 to 52.2, NDF from 41.0 to $52.0 \%$ and crude proteine from 12.3 to $15.8 \%$. Areas with lower PV and lower forage quality were marginal and were found in surveys with high abundance of Sesleria varia (Jacq.) Wettst., or with species usually present in under-grazed pastures. It is necessary to study botanical composition and forage quality of pastures at the farm level, and to utilize the whole grazing surface in order to maintain and restore high-quality forage.
\end{abstract}

\section{Introduction}

Several authors (e.g. Avery, 2001; Ramankutty et al., 2008)

Correspondence: Cristina Pornaro, Department of Agronomy, Food, Natural resources, Animals, and Environment (DAFNAE), University of Padova, Viale dell'Università 16, 35020 Legnaro (PD), Italy. Tel.: +39.049.827.2855.

E-mail: cristina.pornaro@unipd.it

Key words: Crude protein; NDF; pasture value; spatial distribution.

Received for publication: 15 May 2019.

Revision received: 2 August 2019.

Accepted for publication: 20 August 2019.

(C) Copyright: the Author(s), 2019

Licensee PAGEPress, Italy

Italian Journal of Agronomy 2019; 14:1480

doi:10.4081/ija.2019.1480

This article is distributed under the terms of the Creative Commons Attribution Noncommercial License (by-nc 4.0) which permits any noncommercial use, distribution, and reproduction in any medium, provided the original author(s) and source are credited. have estimated that less than $40 \%$ of the earth's surface can be used for agriculture, and $26 \%$ is classified as pasture. Pastures are generally located in areas not suitable for intensive crops farming, where soil is shallow and poor in fertility (Godfray et al., 2010), thereby providing habitats that are essential for maintaining the landscape and preserving the environment. Among the ecological functions provided by pastures, conservation of unique biodiversity, regulation of physical and chemical fluxes in ecosystems, mitigation of pollution, and preservation of landscapes have been recognized as the most relevant (e.g. Gibon, 2005; Lemaire et al., 2005; Pornaro et al., 2017). Pastures are characterized by high biological diversity due to the richness in plant species. In fact, several studies comparing shrub or forest vegetation with grassland plant composition showed a higher number of species in the latter (MacDonald et al., 2000; Pornaro et al., 2013; Koch et al., 2015). These ecosystems are vulnerable to different kinds of degradation caused by climate change and human activities. Several studies revealed that pasture ecosystems are being degraded (UNCCD, 1994; Conant et al., 2001; Safriel et al., 2005; Veron et al., 2006), and that the main cause of degradation is over- or under-grazing. Overgrazing has negative effects on plant vegetation, vegetation ground cover, and soil structure (Van de Ven et al., 1989; Hiernaux et al., 1999; Manzano et al., 2000). However, as an effect of under-grazing, pastures are also subject to reforestation (Conti and Fagarazzi, 2004) with consequent changed in botanical composition of herbaceous layer (Pornaro et al., 2013). It is important to maintain pastures and in general, dairy and meat systems-based grasslands to preserve biodiversity (Tallowin et al., 2005), and also, as reported by Peyraud et al. (2010), many other important environmental services including soil functionality and preservation of the landscape (Avery, 2001).

Pastures located in the Alps are unique in their species richness, as they are generally composed of complex plant communities, mainly grasses (Poaceae) and, to a lesser extent, legumes and other forbs (Troxler, 1990; Scehovic, 1991; Pornaro, 2012). Their botanical composition is largely dependent on altitude, gradient, and climatic and edaphic factors (Jeangros et al., 1999). However, differences in botanical composition also occur at a finer spatial scale, especially in mountainous regions where various site conditions, such as terrain slope, differ at a scale of meters. Botanical composition of pastures is the result of grazing management and environmental factors such as temperature (Buxton and Fales, 1994; Van Soest, 1994; Ziliotto et al., 2004), water deficit (Halim et al., 1989; Ziliotto et al., 2004), solar radiation (Lechtenberg et al., 1971; Buxton and Fales, 1994), and soil nutrient availability (Buxton and Fales, 1994; Ziliotto et al., 2004; Gibon, 2005).

It is well-documented that the concentrations of soil nutrients, mainly nitrogen and phosphorous, affect plant diversity (Güsewell et al., 2012; Gardarin et al., 2014). In alpine environments, soil nutrient status is generally associated with plant diversity and forage quality; low concentrations of nutrients favour the dominance 
of few oligotrophic species in the sward, whereas high concentrations promote the dominance of a few nitrophilous plants (Aerts and Chapin, 1999; Iussig et al., 2015; Orlandi et al., 2016).

Nitrophilous species are generally characterized by low nutritive value or high levels of toxic compounds (Aerts and Chapin, 1999; Iussig et al., 2015; Orlandi et al., 2016). Herbage nutritive value strongly depends on botanical composition and especially on the relative abundance of grasses and legumes. Indeed, the neutral detergent fibre (NDF) concentration of grasses is usually greater than that of legumes (Buxton, 1996; Andueza et al., 2016). Moreover, environmental and agronomic factors also affecting herbage maturity causes fluctuations in forage quality. A decline in forage quality generally occurs as plant maturity advances (Buxton, 1996; Rossignol et al., 2014).

Daget and Poissonet (Daget and Poissonet, 1969) suggested the use of the pastoral value (PV) index to describe the forage quality of vegetation. This index is less influenced by temporal variability than by other forage parameters such as aboveground biomass, organic matter digestibility, or crude protein content. The PV summarizes forage yield, quality, and palatability to livestock and it is directly related to forage energy and alpha-linolenic acid content (Daget and Poissonet, 1969; Ravetto Enri et al., 2017). Similarly, Ellenberg (1974) and Landolt (1977) proposed the use of ecological indicators as site ecological descriptors, which are calculated from the list of species. Such indicators are suited to characterize an area (Tölgyesi et al., 2014) and they are well correlated with the supply of several nutrients (e.g. nitrogen, phosphorous, and potassium) and the potential biomass production of the site (Diekmann, 2003).

Although the importance of mountain pastures in preserving environmental biodiversity (Tallowin et al., 2005) and improving the quality of final products (Martin et al., 2005) is widely recognized, there is very little information about vegetation characteristics of these pastures arising from farm-level data. Studying vegetation at a small spatial scale is essential to understand the variability in vegetation properties and the impact of specific management actions. In the summer pastures of the southern European Alps, where environmental conditions change rapidly and substantially, analysing pasture characteristics at a fine scale is of great importance in guiding local decisions. The present study aimed to understand the current botanical composition and herbage quality of a summer pasture in the Veneto Region in the southern Alps, which is essential for defining any site-based management strategies.

\section{Materials and methods}

The study was conducted at the summer pasture of Malga Serona (61 ha of which 40 ha is grazing surface), a dairy summer farm located in the Veneto Region of northeastern Italy (latitude 45.7949 N, longitude 11.4933 E). The local climate is classified as subpolar oceanic, according to Köppen's classification (Kottek et al., 2006). The area of study is located between 1140 and $1360 \mathrm{~m}$ a.s.1. and it is characterized by an annual mean temperature of $6.8^{\circ} \mathrm{C}$ and precipitation of $1383 \mathrm{~mm}$. The herd was managed with continuous grazing management from the end of May to the end of September. In the summer of 2016, during a preliminary inspection, the grazed surface was split into 15 areas (Table 1), each homogeneous in vegetation structure and composition. The homogeneity of each area was visually assessed based on herbaceous component, presence of trees and shrubs, terrain slope, and rocky outcrops. A number of sampling points between three and six, depending on the herbaceous layer homogeneity and area size, was included in each area for a total of forty sampling points. Their positions were identified in the field using a GPS device (Topcon GMS-2). At each point, botanical surveys were performed using the vertical point-quadrat method (Daget and Poissonet, 1971) along linear vegetation transects, recording plant species touching a steel needle for each point quadrat. In order to study pasture botanical composition and herbage quality, we performed $10-\mathrm{m}$ linear vegetation transects with point quadrats every 50 -cm interval. Species nomenclature followed Pignatti (Pignatti, 1982). Furthermore, at each point, soil depth was measured by striking an iron rod with a hammer until the bedrock was reached, and herbage mass was collected cutting the vegetation in a $100 \times 100 \mathrm{~cm}$ area at $1-\mathrm{cm}$ height by means of a handheld brush cutter. For each survey, species relative abundance (SRA) was calculated and used to detect the proportions of different species according to the equation of Daget and Poissonet (1971).

The number of species was calculated for each survey. Landolt indicator values (Landolt et al., 2010) were attributed to each recorded plant species. Afterwards, an average Landolt index was calculated for each survey using species SRA. To estimate PV, an index of specific quality (ISQ) was assigned to each species (Daget and Poissonet, 1971; Cavallero et al., 2007). The ISQ depends on the herd preference, morphology, structure, and productivity of the plant species and it ranges from -1 (harmful) to 8 (high quality) (Staehlin, 1970; Klapp, 1971). The PV was calculated as follow for each survey:

$$
P V=\sum_{\mathrm{i}}^{\mathrm{n}}\left(S R A_{i} * I S Q_{i}\right) * 0.2
$$

Herbage samples were first oven-dried at $65^{\circ} \mathrm{C}$ for $48 \mathrm{~h}$ and weighed to determine dry matter (DM $\left.\left[\mathrm{t} \mathrm{ha}^{-1}\right]\right)$; subsequently, concentrations of fibre, NDF, acid detergent fibre (ADF), acid detergent lignin (ADL), crude protein (CP), ash, and ether extract (EE) were determined via near-infrared reflectance spectroscopy (NIRS) analysis (model 5000; NIRSystems, Silver Springs, MD).

The matrix of species derived from botanical surveys was subjected to hierarchical cluster analysis: the distance matrix was computed with the Euclidean method and the average linkage method (Ward, 1963) was used for the cluster analysis. Spearman's correlation coefficients between Landolt indicator values, number of species, soil depth, and nutritional values were calculated. The statistical analyses were performed using $\mathrm{R}$ version 3.4.0 (R Development Core Team 2017). Rasters of NDF, crude protein, and PV spatial distribution were generated through inverse distance weighted interpolation using QGIS 2.18.2 software (QGIS Development Team, 2018).

\section{Results}

\section{Botanical characterisation}

Based on the cluster analysis results, we identified 9 groups, as reported in Figure 1. Festuca rubra L., Carex spp., and Sesleria varia (Jacq.) Wettst. were found in all surveys of Groups 1, 2, and 3 , although with different percentages (Table 2). The botanical composition of surveys that fell into Group 1 displayed a percentage of F. rubra and Carex spp. from 10 to 20 and from 13 to 20, respectively, with a low percentage of $S$. varia $(0-12 \%)$. Furthermore, in all surveys, Bromus erectus Hudson (2-16\%), Briza media L. (8\%), Hippocrepis comosa L. (6-7\%), and 
Trifolium repens L. (2-4\%) were recorded. Surveys included in Group 2 displayed a percentage of F. rubra from 5 to 10, Carex spp. from 18 to 20, and $S$. varia from 9 to 25 (Table 2). Crocus albiflorus Kit. and Galium mollugo L. were also present with percentages varying from 5 to 9 , and from 1 to 5 , respectively. As with Group 1, in Group 3, the percentage of $S$. varia was very low in all surveys, and F. rubra and Carex spp. displayed percentages ranging from 10 to 21 and from 4 to 11 respectively. In surveys included in this Group, Ranunculus acris L., Achillea millefolium L., and Lotus corniculatus L. displayed percentages from 2 to 10, from 1 to 8 , and from 2 to 9 , respectively. Thymus serpyllum L. s.s. was also recorded in all surveys, with a percentage ranging from 1 to 12. Groups 4, 5, and 6 included surveys with very low percentages of F. rubra, Carex spp., and S. varia (Table 2). Each area of this group was characterized by a single dominant species. Group 4 was characterized by high abundance of Brachypodium pinnatum (L.) Beauv. (20-21\%), accompanied by Cerastium alpinum L. (7$8 \%$ ), Koeleria pyramidata (Lam.) Domin (2-4\%), and Carlina acaulis L. (2-4\%). Group 5 displayed low of Carex spp. (1-3\%), accompanied by Helleborus viridis L. (1-6\%), R. acris (1-6\%), and C. acaulis (1-7\%). The surveys comprising Group 6 had $17 \%$ Dactylis glomerata L., together with Festuca arundinacea Schreber (8\%), Lolium perenne L. (8\%), and Ranunculus repens L. $(15 \%)$. In contrast to Groups 1,2 , and 3, S. varia was absent in Groups 7, 8, and 9, while F. rubra and Carex spp. were both present (Table 2). The botanical composition of surveys that fell into Group 7 displayed a percentage of $F$. rubra from 8 to 20, with low percentages of Carex spp. (1-7\%). Furthermore, in all surveys, Poa pratensis L. (4-16\%), Achillea millefolium L. (10-12\%), and T. repens (6-18\%) were recorded. In Group 8, Carex spp. and $F$. rubra displayed percentages ranging from 18 to 25 and from 12 to 18, respectively. In surveys included in this group, Luzula campestris (L.) DC., A. millefolium, and T. repens displayed percentages from 3 to 8 , from 5 to 10 , and from 7 to 16 , respectively. Surveys included in Group 9 displayed a percentage of F. rubra from 5 to 13, and Carex spp. from 5 to 20. Koeleria pyramidata (617\%), T. repens (6-14\%), A. millefolium (3-9\%), and Taraxacum officinale Weber (1-4\%) were also present.

\section{Landolt indicator values and nutritional values}

The analysis revealed significant differences among groups for all Landolt indicator values. We notice that Group 7 and 8 displayed higher soil humidity values than all other groups, while Group 4 displayed lower soil humidity values than Groups 2, 3, 5, 7, 8, and 9 (Table 3). For light needs, Group 1 reached the highest value. Group 7 reached the highest value for nutrients in the soil. However, these differences do not have a practical meaning, as often when rounding Landolt indicator values to the unit, differences cannot be explained with the indicator value meaning. Regarding soil depth, Group 7 displayed values lower than Groups $3,5,8$, and 9 . The group with the highest number of species was Group 3; furthermore, Group 8 had lower species richness than Groups 1, 2, 5, 7, and 9. Group 7 displayed the highest pastoral value while Groups 2, 4, and 5 displayed the lowest. Differences were also found in nutritional values, especially protein content, where Groups 7 and 9 displayed higher values than Groups 2, 4, 5, and 8 ; moreover, these two groups had lower fibre content than Groups 2, 4, and 5. Finally, Groups 7 and 8 had lower NDF and ADF content in comparison with Groups 1, 2, 3, 4, and 5.

It is interesting to note that soil humidity, soil reaction, soil nutrients, and soil aeration were significantly correlated with nutritional values (Table 4). Moreover, soil humidity, soil nutrients, and soil reaction were positively correlated with fibrous fractions. As expected, protein content was negatively correlated with fibrous fractions, while fibrous fractions were positively correlated with each other. In the same way, pastoral value was positively correlated with protein and negatively correlated with fibrous fractions. Number of species was correlated only with light needs.

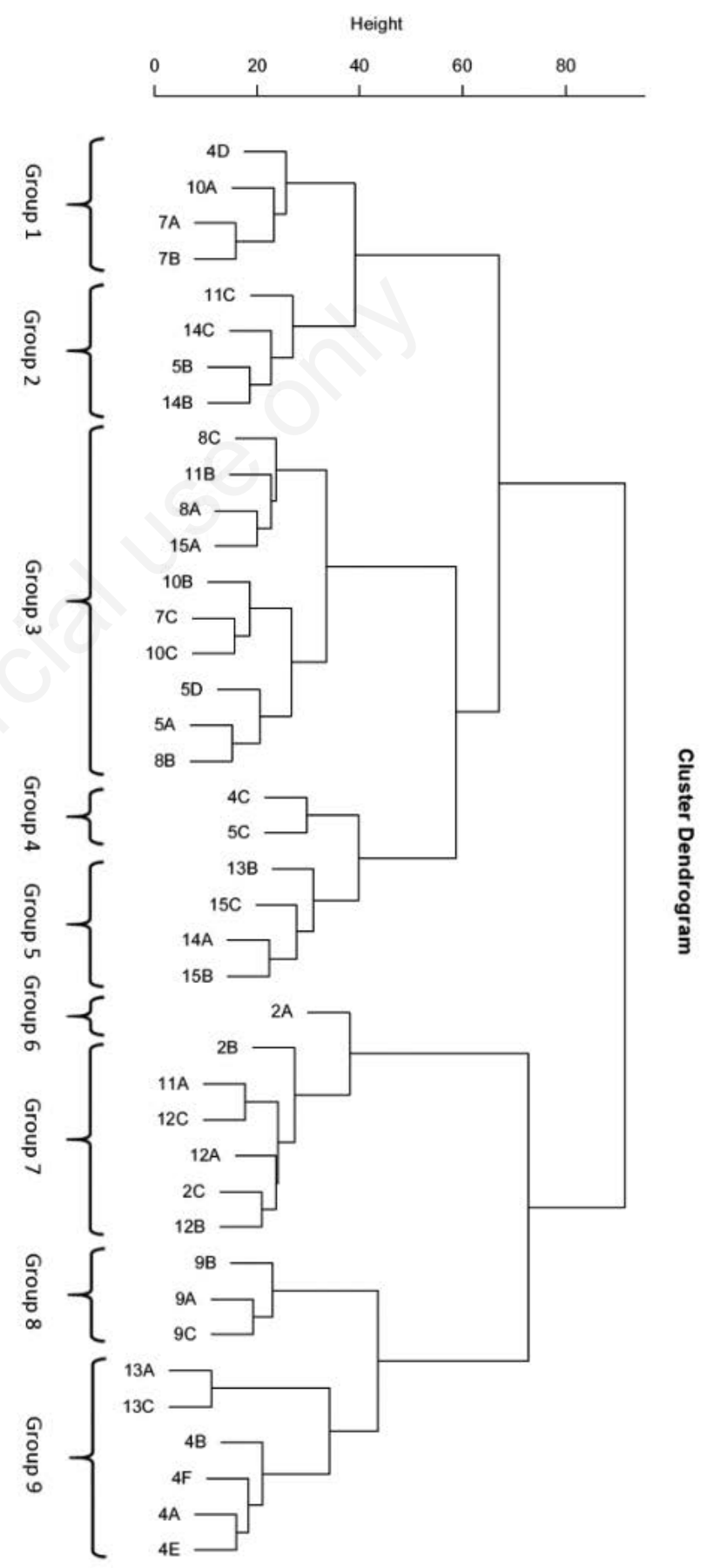

Figure 1. Dendrogram from Cluster analysis of botanical surveys performed in the grazing surface of Malga Serona (northeastern Italy). Groups resulted from the analysis are reported below the graph. Labels of each survey is reported in the dendrogram. 


\section{Spatial distribution of forage quality}

Distribution of pasture surface for each group resulting from the cluster analysis is shown in Figure 2A. Group 3 was the largest with 13.21 ha, while Groups 1, 2, 4, 5, 6, 7, 8, and 9 measured 4.76, $1.31,3.99,2.18,2.12,4.96,2.46$, and 5.21 ha, respectively. Upon observing Figure 2B, it is clear that areas with lower PV are rather far from the farm stables. Except for survey number 4C, which had a PV of 35.4, the pasture surface appeared to be split into two sections, where marginal areas had PV lower than 40, while in those in close proximity to the stable, the PV was higher than 40 . We also

Table 1. Main characteristics of the $\mathbf{1 5}$ homogeneous areas.

\begin{tabular}{lccccc} 
ID area & Slope (\%) & Rocky outcrop (\%) & Vegetation structure & Number of surveys & Area sive (ha) \\
1 & 35 & 15 & Ungrazed forest & 0 & 2.7 \\
2 & 23 & 5 & Pasture & 0 & 5.4 \\
\hline 3 & 34 & 15 & Ungrazed forest & 6 & 13.4 \\
4 & 30 & 20 & Pasture with shrubs and trees & 4 & 7.1 \\
\hline 5 & 31 & 10 & Pasture with scattered trees & 0 & 5.8 \\
6 & 43 & 10 & Ungrazed forest & 3 & 5.1 \\
\hline 7 & 31 & 10 & Pasture with shrubs and trees & 3 & 5.2 \\
8 & 31 & 10 & Pasture with scattered trees & 3 & 4.7 \\
\hline 9 & 23 & 10 & Pasture & 3 & 2.5 \\
10 & 21 & 10 & Pasture with trees & 3 & 1.9 \\
\hline 11 & 28 & 5 & Pasture & 3 & 1.5 \\
12 & 23 & $<1$ & Pasture with shrubs and trees & & 1.7 \\
\hline
\end{tabular}

Table 2. List of species and their relative abundance (lower percentage value - upper percentage value) selected from the whole species list to describe groups resulting from Cluster analysis.

\begin{tabular}{|c|c|c|c|c|c|c|c|c|c|}
\hline Species & $\begin{array}{c}\text { Group } \\
1\end{array}$ & 2 & 3 & 4 & 5 & 6 & 7 & 8 & 9 \\
\hline Festuca rubra L. & $10-20$ & $5-10$ & $10-21$ & $2-14$ & $11-16$ & & $8-20$ & $12-18$ & $5-13$ \\
\hline Carex spp. & $13-20$ & $18-20$ & $4-11$ & $2-9$ & $1-3$ & & $1-7$ & $18-25$ & $5-20$ \\
\hline Sesleria varia (Jacq.) Wettst. & $0-12$ & $9-25$ & $1-12$ & $5-21$ & $7-15$ & & & & \\
\hline Bromus erectus Hudson & $2-16$ & $3-5$ & 3 & $1-12$ & $3-6$ & 2 & $1-6$ & & \\
\hline Briza media L. & $1-8$ & 3 & $1-7$ & $1-2$ & 1 & & $11-12$ & & $2-6$ \\
\hline Hippocrepis comosa L. & $6-7$ & $1-2$ & $1-4$ & 5 & & & & 3 & $1-5$ \\
\hline Trifolium repens L. & $2-4$ & $3-6$ & $1-8$ & & $3-6$ & 9 & $6-18$ & $7-16$ & $6-14$ \\
\hline Crocus albiflorus Kit. & $2-5$ & $5-9$ & $2-12$ & $1-5$ & $6-23$ & 6 & $5-13$ & & $2-11$ \\
\hline Galium mollugo L. & 1 & $1-5$ & $1-5$ & & $4-5$ & & $1-4$ & & $1-6$ \\
\hline Ranunculus acris L. & $1-2$ & $2-8$ & $2-10$ & 1 & $1-6$ & 4 & $2-7$ & $3-7$ & $2-5$ \\
\hline Achillea millefolium L. & $2-4$ & 1 & $1-8$ & $1-2$ & $5-11$ & 4 & $10-12$ & $5-10$ & $3-9$ \\
\hline Lotus corniculatus L. & $4-9$ & $1-9$ & $2-9$ & $2-11$ & $4-6$ & & $1-4$ & $1-7$ & $3-8$ \\
\hline Thymus serpyllum L. s.s. & $4-9$ & 13 & $1-12$ & 4 & & & & & \\
\hline Brachypodium pinnatum (L.) Beauv. & 5 & 5 & $2-12$ & 20-21 & $13-16$ & & & & 3 \\
\hline Cerastium alpinum L. & $7-8$ & $2-6$ & $1-8$ & $7-8$ & 4 & 3 & $1-6$ & & $1-4$ \\
\hline Koeleria pyramidata (Lam.) Domin & $1-7$ & 1 & $1-4$ & $2-4$ & 9 & & $6-7$ & & $6-17$ \\
\hline Carlina acaulis L. & 1 & $1-4$ & $1-3$ & $2-4$ & $1-7$ & & & & $1-3$ \\
\hline Helleborus viridis L. & & & 1 & & $1-6$ & 1 & & 1 & 1 \\
\hline Dactylis glomerata L. & & & $4-10$ & 2 & 1 & 17 & $1-6$ & 2 & 1 \\
\hline Festuca arundinacea Schreber & $1-4$ & 1 & $1-7$ & 12 & $3-6$ & 8 & $1-4$ & $13-14$ & 1-6 \\
\hline Lolium perenne L. & & & 1 & & 1 & 8 & $1-6$ & & $3-4$ \\
\hline Ranunculus repens L. & 2 & $1-2$ & 2 & 1 & & 15 & $1-5$ & 1 & $2-5$ \\
\hline Poa pratensis L. & & 2 & $1-3$ & & & 1 & $4-16$ & & $2-5$ \\
\hline Luzula campestris (L.) DC. & 2 & 1 & 1-6 & & 1 & & $1-3$ & $3-8$ & $2-7$ \\
\hline Taraxacum officinale Weber (aggregato) & $5-7$ & & $1-8$ & & 1 & 4 & $2-12$ & $1-7$ & $1-4$ \\
\hline
\end{tabular}


observed two main areas for NDF content: one with percentages of NDF lower than 46.4, and another with higher percentages. Due to the strong correlation between NDF and crude protein, spatial distribution of crude protein reflected that of NDF, with values lower than 14.0 where NDF percentage was high, and values higher than 14.0 where NDF percentage was low. While spatial distribution of PV seemed to reflect spatial distribution of groups individuated with cluster analysis (Figure 2A), spatial distribution of NDF (Figure 2C) and crude protein (Figure 2D) was not assimilable to cluster groups. For example, surveys $10 \mathrm{~A}$ and $10 \mathrm{C}$ displayed average PV values and average crude protein contents but high NDF contents. Additionally, surveys 7A and 7B had PV values of 45.7 and 44.9, respectively, and NDF content of 43.6 and $44.8 \%$, respectively, but crude protein content of 13.0 and 13.8, respectively.

\section{Discussion and Conclusions}

Our findings confirmed the spatial heterogeneity in the botanical composition of an alpine pasture at a small scale (Pornaro et al., 2013; Homburger et al., 2015) and highlighted the presence of species with good fodder values across all pasture areas. Nevertheless, the number of species found in the present study is lower than that found by Pornaro et al. (2013) in pastures located few kilometres west of the study site at the same altitude. This difference may be due to different survey methods used and number of point quadrats detected for each line transect. However, it is in line with species richness found by Pittarello et al. (2018) in a study conducted in the Piedmont Region of the Western Italian Alps, even if the number of point quadrats per survey was higher in the study conducted by Pittarello et al. (2018). The different number of species found in this study compared with that reported by Pornaro et al. (2013) is probably due to the different survey methods used. In fact, in the previous investigation (Pornaro et al., 2013), surveys were performed by recording the number of species in a $100-\mathrm{m}^{2}$ quadrat, while in the present study and in that by Pittarello et al. (2018), surveys were performed using the vertical point-quadrat method (as described in section 2). Nevertheless, the grazing surface was mainly composed of species with low pastoral value, such as F. rubra, Carex spp., and $S$. varia of Groups 1, 2, 3, 7,8 , and 9 , or $B$. pinnatum of Group 4 . The sole exception was Group 6, where we found species more suited to forage production, such as D. glomerata, F. arundinacea, and L. perenne. The vegetation of the study area was more xeric than the vegetation described by Pornaro (2012), who reported for pastures at the same altitude great abundances of L. perenne, Cynosurus cristatus L., F. rubra, Festuca pratensis Hudson, and Phleum pratense L., but did not mention the presence of $S$. varia, which is abundant in our study area. Moreover, she found a diffuse process of vegetation degradation due to under-grazing that in the present study was located in few marginal or more sloping areas where shrub encroachment phenomena were observed (Table 1).

In our study, we observed significant differences in botanical composition and forage quality within the study area. This confirms what was reported by other authors (Argenti and Lombardi, 2012; Homburger et al., 2015; Pittarello et al., 2018) and is a management issue because inappropriate pasture management results in pasture degradation (Bailey, 1995; Adler et al., 2001; Argenti and Lombardi, 2012; Pornaro et al., 2013). We found that the PV varied from 35.6 to 52.2 (Figure 2B), the NDF content from 41.0 to $52.0 \%$ (Figure 2C), and the crude protein content from 12.3 to $15.8 \%$ (Figure 2D). As reported by Buxton (1996), these values indicate a good quality of pasture herbage. However, forage quality of areas with higher values are comparable to the quality of $L$. perenne meadow at the first harvest, while forage quality of areas with lower values are comparable to the quality of $L$. perenne meadow at the second harvest (Huyghe, 2010). We observed that areas with low PV and poor forage quality are included in Groups

Table 3. Landolt indicator values, pastoral values, number of species (Nsp), soil depth, and nutritional values (NDF, ADF, ADL, Fibre, $\mathrm{EE}$, and Ash) of groups resulting from Cluster analysis (mean \pm standard error).

\begin{tabular}{|c|c|c|c|c|c|c|c|c|c|}
\hline & \multicolumn{9}{|c|}{ Group } \\
\hline & 1 & 2 & 3 & 4 & 5 & 6 & 7 & 8 & 9 \\
\hline Soil humidity & $2.4 \pm 0.1$ & $2.6 \pm 0.1$ & $2.7 \pm 0.1$ & $2.3 \pm 0.2$ & $2.7 \pm 0.1$ & 3.2 & $2.8 \pm 0.0$ & $2.9 \pm 0.1$ & $2.7 \pm 0.1$ \\
\hline Light needs & $4.0 \pm 0.0$ & $3.9 \pm 0.0$ & $3.7 \pm 0.1$ & $3.8 \pm 0.0$ & $3.7 \pm 0.1$ & 3.5 & $3.8 \pm 0.0$ & $3.9 \pm 0.0$ & $3.8 \pm 0.1$ \\
\hline Temperature needs & $2.4 \pm 0.1$ & $2.4 \pm 0.0$ & $2.4 \pm 0.1$ & $2.5 \pm 0.0$ & $2.4 \pm 0.1$ & 3.1 & $2.6 \pm 0.1$ & $2.4 \pm 0.1$ & $2.5 \pm 0.1$ \\
\hline Continentality & $3.2 \pm 0.0$ & $3.2 \pm 0.0$ & $3.0 \pm 0.0$ & $3.2 \pm 0.1$ & $3.0 \pm 0.0$ & 3.0 & $3.1 \pm 0.0$ & $3.1 \pm 0.1$ & $3.2 \pm 0.1$ \\
\hline Soil reaction $(\mathrm{pH})$ & $3.3 \pm 0.1$ & $3.2 \pm 0.1$ & $3.0 \pm 0.1$ & $3.5 \pm 0.1$ & $3.1 \pm 0.1$ & 3.1 & $3.0 \pm 0.0$ & $3.2 \pm 0.1$ & $3.0 \pm 0.1$ \\
\hline Nutrients in the soil & $2.6 \pm 0.1$ & $2.8 \pm 0.1$ & $3.0 \pm 0.1$ & $2.7 \pm 0.2$ & $3.1 \pm 0.1$ & 3.8 & $3.4 \pm 0.0$ & $3.2 \pm 0.1$ & $3.0 \pm 0.1$ \\
\hline Humus content & $3.1 \pm 0.01$ & $3.2 \pm 0.0$ & $3.2 \pm 0.1$ & $3.1 \pm 0.0$ & $3.2 \pm 0.0$ & 3.2 & $3.3 \pm 0.0$ & $3.0 \pm 0.0$ & $3.1 \pm 0.1$ \\
\hline Aeration of the soil & $3.8 \pm 0.1$ & $3.6 \pm 0.2$ & $4.0 \pm 0.1$ & $3.7 \pm 0.3$ & $3.9 \pm 0.1$ & 4.4 & $4.2 \pm 0.0$ & $4.2 \pm 0.1$ & $3.9 \pm 0.1$ \\
\hline Pastoral value & $44.8 \pm 0.8$ & $32.9 \pm 1.3$ & $42.9 \pm 2.8$ & $36.1 \pm 3.2$ & $31.9 \pm 3.2$ & 52.7 & $56.4 \pm 2.3$ & $47.9 \pm 2.4$ & $48.4 \pm 1.4$ \\
\hline Nsp & $19.5 \pm 1.0$ & $19.0 \pm 1.8$ & $25.5 \pm 1.1$ & $17.5 \pm 2.5$ & $22.5 \pm 2.4$ & 17.0 & $20.6 \pm 1.1$ & $15.3 \pm 2.1$ & $19.7 \pm 2.7$ \\
\hline Soil depth & $15.9 \pm 2.9$ & $18.2 \pm 2.9$ & $19.2 \pm 2.1$ & $18.8 \pm 5.0$ & $25.9 \pm 8.6$ & 13.3 & $15.0 \pm 1.7$ & $25.5 \pm 4.9$ & $28.2 \pm 4.9$ \\
\hline Protein & $14.4 \pm 0.7$ & $13.2 \pm 0.6$ & $14.1 \pm 0.5$ & $12.0 \pm 0.9$ & $12.1 \pm 0.8$ & 14.7 & $15.3 \pm 0.5$ & $14.0 \pm 0.5$ & $15.2 \pm 0.5$ \\
\hline NDF & $46.5 \pm 2.2$ & $50.9 \pm 1.9$ & $47.0 \pm 1.8$ & $55.4 \pm 4.6$ & $50.5 \pm 3.3$ & 40.8 & $39.5 \pm 2.0$ & $40.9 \pm 3.0$ & $46.3 \pm 3.8$ \\
\hline $\mathrm{ADF}$ & $27.2 \pm 1.2$ & $31.3 \pm 1.4$ & $27.5 \pm 1.0$ & $29.9 \pm 2.1$ & $31.4 \pm 2.3$ & 23.7 & $24.6 \pm 0.8$ & $25.1 \pm 0.9$ & $27.3 \pm 1.6$ \\
\hline $\mathrm{ADL}$ & $4.4 \pm 0.2$ & $6.6 \pm 1.0$ & $4.3 \pm 0.3$ & $3.8 \pm 0.5$ & $6.4 \pm 10.6$ & 2.4 & $3.8 \pm 0.4$ & $3.7 \pm 0.1$ & $4.1 \pm 0.2$ \\
\hline Fibre & $22.6 \pm 1.0$ & $24.9 \pm 0.9$ & $23.4 \pm 0.9$ & $26.2 \pm 2.5$ & $25.5 \pm 1.4$ & 20.9 & $20.5 \pm 0.9$ & $21.5 \pm 0.7$ & $23.2 \pm 1.4$ \\
\hline $\mathrm{EE}$ & $2.1 \pm 0.1$ & $1.9 \pm 0.0$ & $2.1 \pm 0.1$ & $2.0 \pm 0.0$ & $2.0 \pm 0.1$ & 2.3 & $2.1 \pm 0.1$ & $2.0 \pm 0.1$ & $2.1 \pm 0.1$ \\
\hline Ash & $4.9 \pm 0.6$ & $4.1 \pm 0.6$ & $4.3 \pm 0.4$ & $2.8 \pm 1.5$ & $3.8 \pm 0.4$ & 6.0 & $6.6 \pm 0.7$ & $5.6 \pm 0.6$ & $4.5 \pm 0.5$ \\
\hline
\end{tabular}



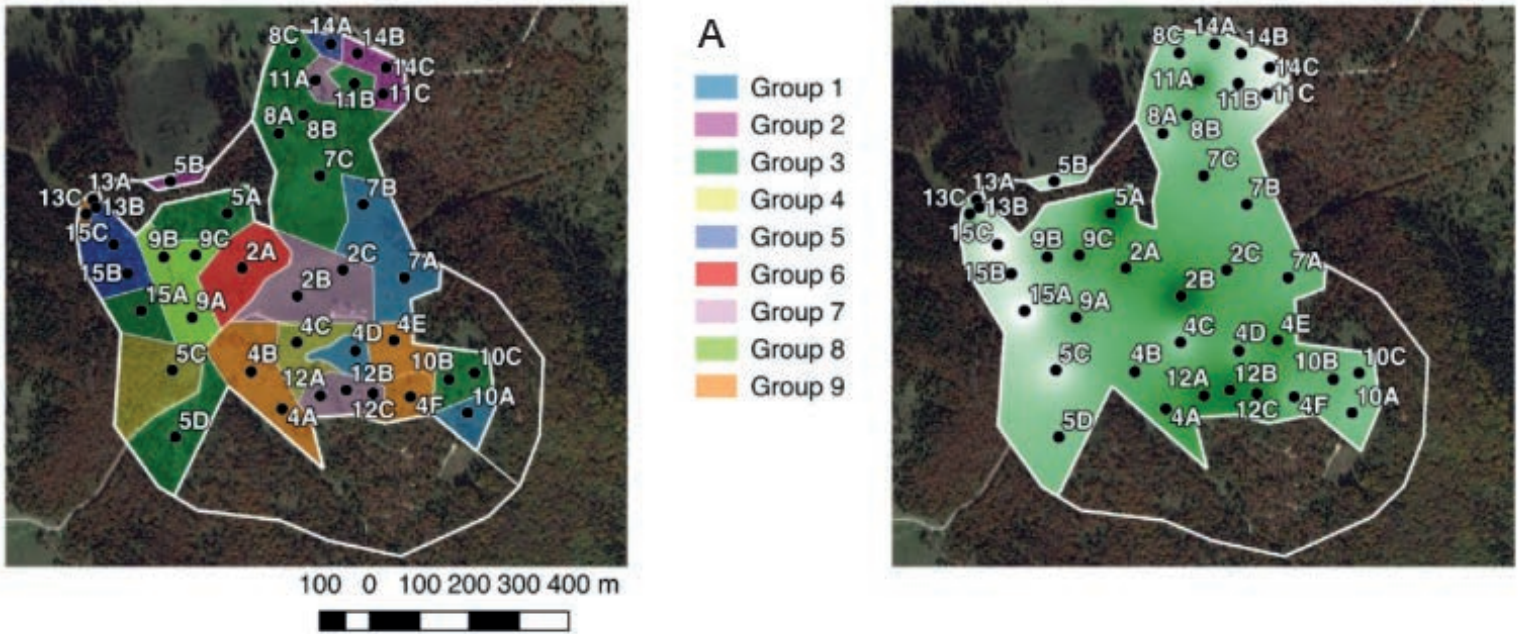

B

\begin{tabular}{|}
$25-30$ \\
$30-35$ \\
$35-40$ \\
$40-45$ \\
$45-50$ \\
$50-55$
\end{tabular}
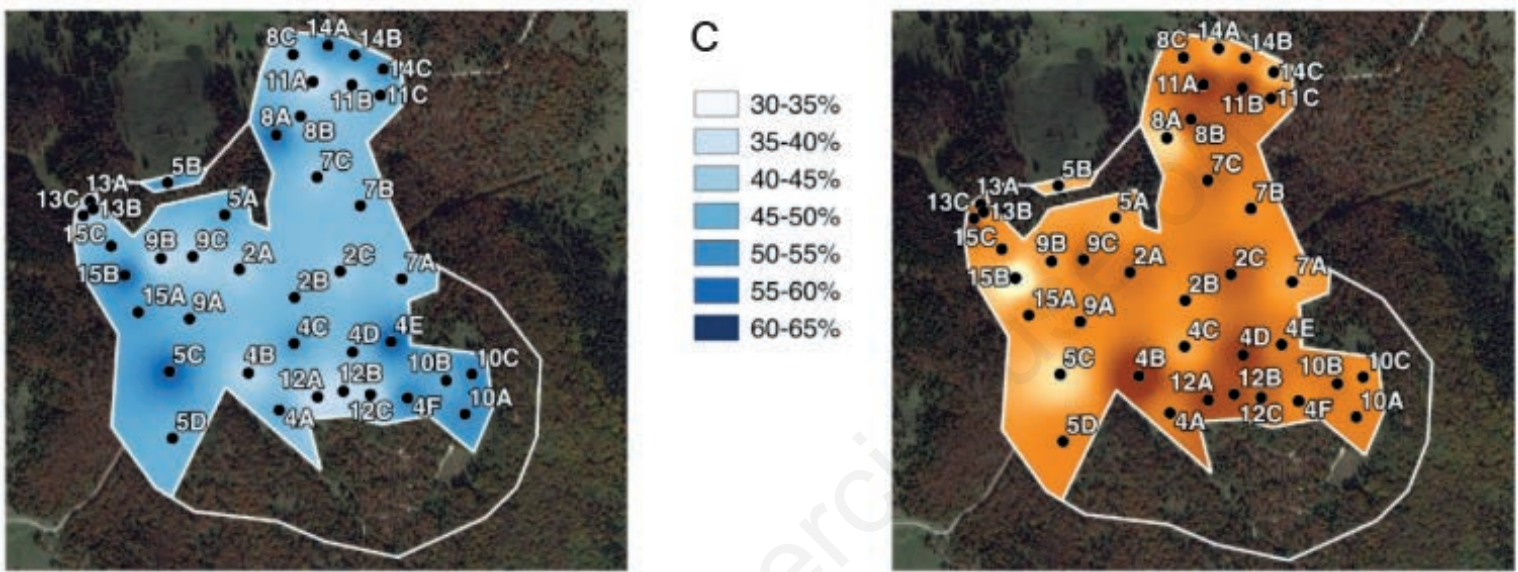

D

Figure 2. Spatial distribution of (A) groups resulting from cluster analysis; (B) pastoral value (PV); (C) herbage NDF content; (D) herbage crude protein content.

Table 4. Spearman's correlation coefficients between Landolt indicator values, pastoral values, number of species (Nsp), soil depth, and nutritional values. Coefficients are reported for significant correlations only.

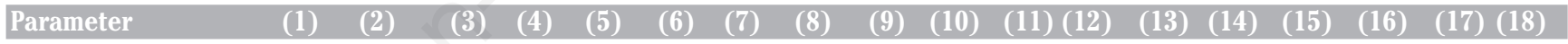

(1) Soil humidity

(2) Light needs

(3)Temperature needs $0.36 \quad /$

(4) Continentality / $0.77 \quad /$

(5) Soil reaction $(\mathrm{pH}) \quad / \quad 0.48 \quad / \quad 0.51$

$\begin{array}{lcccccc}\text { (6) Nutrient in the soil } & 0.90 & / & 0.55 & / & / & \\ \text { (7) Humus content } & 0.44 & 0.38 & 0.32 & / & / & 0.44\end{array}$

(8) Aeration of the soil $\quad 0.79 \quad / \quad 0.46 \quad / \quad / \quad 0.81 \quad 0.37$

\begin{tabular}{lllllllll}
\hline (9) Pastoral value $\quad 0.40$ & $/$ & 0.37 & $/$ & $/$ & 0.56 & $/$ & 0.58
\end{tabular}

(10) Nsp

(11) Soil depth

(12) Protein

$\begin{array}{lllllcccccccc}\text { (13) NDF } & -0.49 & / & / & / & 0.44 & -0.47 & / & -0.43 & -0.44 & / & / & -0.73\end{array}$

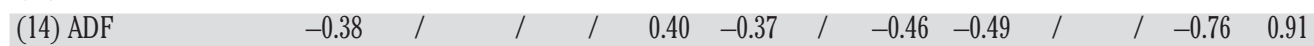

\begin{tabular}{lllllllllllllll}
\hline$(15) \mathrm{ADL}$ & $/$ & $/$ & $/$ & $/$ & $/$ & $/$ & $/$ & -0.49 & -0.52 & $/$ & $/$ & -0.59 & 0.48 & 0.73
\end{tabular}

$\begin{array}{llllllllllllllll}\text { (16) Fibre } & -0.37 & / & / & / & 0.42 & -0.37 & / & -0.37 & -0.43 & / & / & -0.77 & 0.97 & 0.94 & 0.51\end{array}$

\begin{tabular}{lllllllllllllllllll}
\hline$(17) \mathrm{EE}$ & 0.32 & $/$ & $/$ & $/$ & $/$ & 0.34 & $/$ & $/$ & $/$ & $/$ & $/$ & 0.52 & -0.56 & -0.43 & -0.37 & -0.45
\end{tabular}

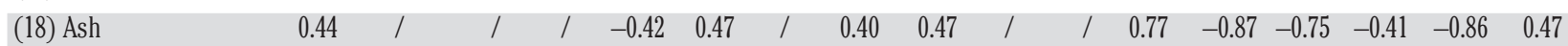


2, 3, and 5. Groups 2 and 3 differed from the others in the high abundance of $S$. varia, while Group 5 was characterized by species that usually composed pastures edges (H. viridis) or under-grazed pastures (Carex spp.).

This case study highlights a thorny issue in mountain pasture management. Several authors agree that it is important to maintain mountain pastures to preserve environmental services. However, milk production needs and the high labour inputs required often lead to limited control over animals. Herds usually avoid marginal areas with low-quality forage, which causes further degradation of botanical composition in these areas. The present case study points out that number of species and nutritional values of the grazed surface are in line with neighbour pastures, with better features in areas located near the stable than marginal areas. Since a consequence of continuous grazing management is undergrazing of marginal and more sloping areas, the results suggest that the pasture of Malga Serona may be maintained in both its biodiversity and nutritional value of forage by grazing the entire surface with the same intensity, encouraging livestock to also graze marginal areas that contain species with adequate ISQ to support livestock health and production. Grazing offers a potentially important tool for conservation management because of its influence on habitat structure and biodiversity (Collins et al., 1980). However, our results highlight that grazing can also be used as a tool to improve forage quality of marginal areas.

\section{References}

Aerts R, Chapin FS, 1999. The mineral nutrition of wild plants revisited: a re-evaluation of processes and patterns. Adv. Ecol. Res. 30:1-67.

Adler P, Raff D, Lauenroth W, 2001. The effect of grazing on the spatial heterogeneity of vegetation. Oecologia 128:465-79.

Andueza D, Rodrigues AM, Picard F, Rossignol N, Baumont R, Cecato U, Farruggia A, 2016. Relationships between botanical composition, yield and forage quality of permanent grasslands over the first growth cycle. Grass Forage Sci. 71:366-78.

Argenti G, Lombardi G, 2012. The pasture-type approach for mountain pasture description and management. Ital. J. Agron. 7:e39.

Avery M, 2001. Habitat conservation - a framework for future action. Ecos. 22:3-7.

Bailey AW, 1995. Managing Canadian Rangelands as a Sustainable Resource: Policy Issues. Not numbered volumes. pp 5-7 in Proc. 5th International Rangeland Congress, Utah, USA.

Buxton DR, 1996. Quality-related characteristics of forages as influenced by plant environment and agronomic factors. Anim. Feed. Sci. Tech. 59:37-49.

Buxton DR, Fales SL, 1994. Plant environment and quality. In: Fahey Jr. GD (ed.) Forage quality, evaluation, and utilization. American Society of Agronomy, Madison, WI, pp 155-199.

Cavallero A, Aceto P, Gorlier A, Lombardi G, Lonati M, Martinasso B, Tagliatori C, 2007. I tipi pastorali delle Alpi piemontesi. Alberto Perdisa Editore, Bologna, Italy.

Collins SL, Knapp AK, Briggs JM, Blair JM, Steinauer EM, 1980. Modulation of diversity by grazing and mowing in native tallgrass prairie. Science 280:745-7.

Conant RT, Paustian K, Elliott ET, 2001. Grassland management and conversion into grassland: effects on soil carbon. Ecol. Appl. 11:343-55.

Conti G, Fagarazzi L, 2004. Sustainable mountain development and the key-issue of abandonment of marginal rural areas. Eur
J Plan 11:1-20.

Daget P, Poissonet J, 1969. Analyse phytologique des prairies: applications agronomiques. Document 48, CNRS-CEPE, Montpellier, pp. 67.

Daget P, Poissonet J, 1971. Une métode d'analyse phytologique des prairies. Ann. Agron. 22:5-41.

Diekmann M, 2003. Species indicator values as an important tool in applied plant ecology - a review. Basic. Appl. Ecol. 4:493-506.

Ellenberg H, 1974. Indicator values of vascular plants in central Europe. Sci. Geobot. 9.

Gardarin A, Garnier É, Carrère P, Cruz P, Andueza D, Bonis A, Colace MP, Dumont B, Duru M, Farruggia A, Gaucherand S, Grigulis K, Kernéïs É, Lavorel S, Louault F, Loucougaray G, Mesléard F, Yavercovski N, Kazakou E, 2014. Plant traitdigestibility relationships across management and climate gradients in permanent grasslands. J. Appl. Ecol. 51:1207-17.

Gibon A, 2005. Managing grassland for production, the environment and the landscape. Challenges at the farm and the landscape level. Livest. Prod. Sci. 96:11-31.

Godfray HCJ, Beddington JR, Crute IR, Haddad L, Lawrence D, Muir JF, Pretty J, Robinson S, Thomas SM, Toulmin C, 2010. Food Security: The Challenge of Feeding 9 Billion People. Science 327:812-8.

Güsewell S, Peter M, Birrer S, 2012. Altitude modifies species richness-nutrient indicator value relationships in a countrywide survey of grassland vegetation. Ecol. Indic. 20:134-42.

Halim RA, Buxton DR, Hattendorf MJ, Carlson RE, 1989. Water stress effects on alfalfa forage quality after adjustment for maturity differences. Agron. J. 81:189-94.

Hiernaux P, Bielders CL, Valentin C, Bationo A, Fernández-Rivera S, 1999. Effects of livestock grazing on physical and chemical properties of sandy soils in Sahelian rangelands. J. Arid. Environ. 41:231-45.

Homburger H, Lüscher A, Scherer-Lorenzen M, Schneider MK, 2015. Patterns of livestock activity on heterogeneous subalpine pastures reveal distinct responses to spatial autocorrelation, environment and management. Movement. Ecol. 3:1-15.

Huyghe C, 2010. Sustainable use of genetic diversity in forage and turf breeding. Springer Science, Heidelberg, Germany, pp. 572.

Iussig G, Lonati M, Probo M, Hodge S, Lombardi G, 2015. Plant species selection by goats foraging on montane semi-natural grasslands and grazable forestlands in the Italian Alps. Ital. J. Anim. Sci. 14:484-94.

Jeangros B, Scehovic J, Troxler J, Bachmann HJ, Bosset JO, 1999. Comparaison de caractéristiques botaniques et chimiques d'herbages paturés en plaine et en montagne. Fourrages 159:277-92.

Klapp E, 1971. Wiesen und Weiden. 4. Auflage; Paul Parey: Berlin, Hamburg, pp. 620.

Koch B, Edwards PJ, Blanckenhorn WU, Walter T, Hofer G, 2015. Shrub encroachment affects the diversity of plants, butterflies, and grasshoppers on two Swiss subalpine pastures. Arct. Antarct. Alp. Res. 47:345-57.

Kottek M, Grieser J, Beck C, Rudolf B, Rubel F, 2006. World map of the Köppen-Geiger climate classification updated. Meteorol. Z. 15:259-63.

Landolt E, 1977. Ökologische Zeigerwerte zur Schweizer Flora. Veröffentlichtes Geobotanisches Institute ETH Stiftung Rübel, Zürich, Switzerland.

Landolt E, Bäumler B, Erhardt AHO, Klötzli F, Lämmler W, Nobis M, Rudmann-Maurer K, Schweingruber F, Theurillat JP, Urmi EMV, Wohlgemuth T, 2010. Flora indicativa. Ecological indi- 
cator values and biological attributes of the flora of Switzerland and the Alps, 2nd ed.; Haupt Verlag, Bern, Switzerland.

Lechtenberg VL, Holt DA, Youngberg HW, 1971. Diurnal variation in nonstructural carbohydrates, in vitro digestibility, and leaf to stem ratio of alfalfa. Agron. J. 63:719-24.

Lemaire G, Wilkins R, Hodgson J, 2005. Challenges for grassland science: Managing research priorities. Agric. Ecosyst. Environ. 108:99-108.

MacDonald D, Crabtree JR, Wiesinger G, Dax T, Stamou N, Fleury P, Gutierrez Lazpita J, Gibon A, 2000. Agricultural abandonment in mountain areas of Europe: Environmental consequences and policy response. J. Environ. Manag. 59:47-69.

Manzano MG, Návar J, 2000. Processes of desertification by goats overgrazing in the Tamaulipan thornscrub (matorral) in northeastern Mexico. J. Arid. Environ. 44:1-17.

Martin B, Verdier-Metz I, Buchin S, Hurthaud C, Coulon JB, 2005. How do the nature of forages and pasture diversity influence the sensory quality of dairy livestock products? Anim. Sci. 81:205-12.

Orlandi S, Probo M, Sitzia T, Trentanovi G, Garbarino M, Lombardi G, Lonati M, 2016. Environmental and land use determinants of grassland patch diversity in the western and eastern Alps under agro-pastoral abandonment. Biodivers. Conserv. 25:275-93.

Peyraud JL, Van den Pool-van Dasselaar A, Dillon P, Delaby L, 2010. Producing milk from grazing to reconcile economic and environmental performances. Not numbered volume. Pp. 865879 in Proc. 23th General Meeting of the European Grassland Federation, Germany.

Pignatti S, 1982. Flora d'Italia. ed. Edagricole, Bologna, Italy.

Pittarello M, Lonati M, Gorlier A, Perotti E, Probo M, Lombardi G, 2018. Plant diversity and pastoral value in alpine pastures are maximized at different nutrient indicator values. Ecol. Indic. 85:518-24.

Pornaro C, 2012. Effects of wood establishment on plant biodiversity and herbage production of mountain pastures. $\mathrm{PhD}$ thesis, University of Padova, Italy.

Pornaro C, Schneider MK, Leinauer B, Macolino S, 2017. Aboveand belowground patterns in a subalpine grassland-shrub mosaic. Plant Biosyst. 151:493-503.

Pornaro C, Schneider MK, Macolino S, 2013. Plant species loss due to forest succession in Alpine pastures depends on site conditions and observation scale. Biol. Conserv. 161:213-22.

Ramankutty N, Evan AT, Monfreda C, Foley JA, 2008. Farming the planet: 1. Geographic distribution of global agricultural lands in the year 2000. Global Biogeochem. Cy. 22:1.
Ravetto Enri S, Renna M, Probo M, Lussiana C, Battaglini LM, Lonati M, Lombardi G, 2017. Relationships between botanical and chemical composition of forages: a multivariate approach to grasslands in the Western Italian Alps. J. Sci. Food Agric. 97:1252-9.

Rossignol N, Andueza D, Carrere P, Cruz P, Duru M, Fiorelli JL, Michaud A, Plantureux S, Pottier E, Baumont R, 2014. Assessing population maturity of three perennial grass species: influence of phenology and tiller demography along latitudinal and altitudinal gradients. Grass Forage Sci. 69:534-48.

Safriel U, Adeel Z, Niemeijer D, Puigdefabregas J, White R, Lal R, Winslow M, Ziedler J, Prince S, Archer E, King C, Shapiro B, Wessels K, Nielsen T, Portnov B, Reshef I, Thonell J, Lachman E, McNab D, 2005. Dryland systems. In: Hassan R, Scholes R, Ash N (Eds.), The millennium ecosystem assessment, ecosystems and human well-being: current state and trends. Island Press, Washington DC, pp 623-62.

Scehovic J, 1991. Considérations sur la composition chimique dans l'évaluation de la qualité des fourrages des prairies naturelles. Rev. Suisse Agric. 23:305-10.

Staehlin A, 1970. Gutezahlc11 vo11 Pflanzenarten in frischen Grwuifwter. DLG-Verlag, Frankfurt, pp 151.

Tallowin JRB, Rook AJ, Rutter SM, 2005. Impact of grazing management on biodiversity of grassland. Anim. Sci. 81:193-8.

Tölgyesi C, Bátori Z, Erdos L, 2014. Using statistical tests on relative ecological indicator values to compare vegetation units Different approaches and weighting methods. Ecol. Indic. 36:441-6.

Troxler J, 1990. Dynamique de la vegetation et productivite des prairies naturelles de montagne en Suisse. Herba 3:40-5.

UNCCD, 1994. United Nations convention to combat desertification in countries experiencing serious drought and/or desertification, particularly in Africa. A/AC.241/27, Paris, France.

Van de Ven TAM, Fryrear DW, Spaan WP, 1989. Vegetation characteristics and soil loss by wind. J. Soil Water Conserv. 44:47349.

Van Soest PJ, 1994. Nutritional ecology of the ruminant. Cornell University Press, New York, NY, USA.

Veron SR, Paruelo JM, Oesterheld M, 2006. Assessing desertification. J. Arid. Environ. 66:751-63.

Ward JH, 1963. Hierarchical grouping to optimize an objective function. J. Am. Statist. Ass. 58:236-44.

Ziliotto U, Andrich O, Lasen C, Ramanzin M, 2004. Tratti essenziali della tipologia veneta dei pascoli di monte e dintorni. Regione Veneto, Accademia Italiana di Scienze forestali, Venezia. Vol. 1 and Vol. 2. 